QUALITY

Volume 5, Nomor 1, 2017: 19-39

\title{
RESPON GURU DALAM MENYIKAPI PERUBAHAN KURIKULUM (Studi Kasus Pada Madrasah Aliyah Negeri 1 Kudus)
}

\author{
Adri Efferi \\ STAIN Kudus \\ adri.efferi@gmail.com
}

\begin{abstract}
Abstrak
Kurikulum merupakan hal penting dalam dunia pendidikan. Guru memegang peranan penting dalam perubahan sebuah kurikulum. Oleh karena itu, faktor utama penentu keberhasilan pelaksanaan kurikulum adalah pemahaman guru, terhadap inti dari kurikulum tersebut. Penelitian ini bertujuan untuk mengkaji tingkat pemahaman guru tentang kurikulum 2013 dan respon mereka terhadap perubahan tersebut. Penelitian ini menggunakan pendekatan kualitatif dengan wawancara sebagai teknik pengumpulan data yang utama. Setelah melakukan pengumpulan dan analisa data, diperoleh hasil sebagai berikut: berkenaan dengan tingkat pemahaman para guru terhadap kurikulum, kiranya masih perlu senantiasa mendapat perhatian yang serius terutama oleh pimpinan madrasah, seperti: pemahaman guru terhadap prinsip-prinsip pembelajaran, pembuatan RPP dan penilaian yang sesuai dengan Kurikulum 2013. Mengenai respon para guru menyikapi adanya perubahan terhadap kurikulum, terbagi dua yaitu ada yang menerima dan ada juga yang menolak. Meskipun para guru sesungguhnya menyadari bahwa suatu perubahan atau inovasi mengandung arti adanya perubahan dari suatu keadaan yang lama untuk menjadi lebih baik.
\end{abstract}

Kata-kata kunci: Respon dan Kurikulum 2013.

\begin{abstract}
The curriculum is important in the world of education. Teachers play an important role in the change of a curriculum. Therefore, the determining factor for the successful implementation of the curriculum is the understanding of teachers, the core of the curriculum. This study aims to assess the level of teachers' understanding of the curriculum in 2013 and their responses to those changes. This study used a qualitative approach with interviews as the main data collection techniques. After collecting and analyzing the data, the results are as follows: with respect to the level of understanding of the teachers of the curriculum, would still need to be always serious attention especially by the leadership of the madrasas, such as teachers' understanding of the principles of learning, creation of lesson plans and assessment in accordance curriculum 2013. Regarding the response of teachers to address the changes to the curriculum, that is two some accept and some are refused. Although teachers actually realize that a change or innovation implies the change of a condition long to become better.
\end{abstract}

Keywords: Response and Curriculum 2013. 


\section{A. Pendahuluan}

Para pakar dari berbagai disiplin ilmu yang dikuasai, khususnya lagi dari kalangan dunia pendidikan cenderung mempunyai satu kata, bahwa ujung tombak kemajuan atau kemunduran suatu bangsa sangat tergantung pada kualitas pendidikan yang dimiliki oleh bangsa tersebut. Oleh karena itu, terwujudnya pendidikan yang bermutu baik dari sisi perencanaan, proses, evaluasi dan keluarannya merupakan suatu kebutuhan yang sangat penting, dan tidak dapat dibantah lagi dalam kehidupan manusia pada zaman sekarang. Jika pendidikan suatu bangsa dapat menghasilkan manusia yang berkualitas lahir batin, otomatis bangsa tersebut akan maju, damai, dan tenteram. Sebaliknya jika pendidikan suatu bangsa mengalami stagnasi maka bangsa itu akan terbelakang di segala bidang.

Pendidikan harus terus-menerus melakukan adaptasi dan pembenahan diri, untuk menyesuaikan gerak perkembangan ilmu pengetahuan modern dan inovasi teknologi maju, sehingga tetap relevan dan kontektual dengan perubahan zaman. Pendidikan bertugas untuk menyiapkan peserta didik agar dapat mencapai peradaban yang maju melalui perwujudan suasana belajar yang kondusif, kurikulum yang handal, aktivitas pembelajaran yang menarik dan mencerahkan, serta proses pendidikan yang kreatif.

Harus diakui, ketika kita membahas tentang pendidikan banyak aspek yang saling terkait. Baik dari sisi pendidik, peserta didik, kurikulum, metode dan media pembelajaran, sarana prasarana, biaya dan lain-lain. Satu dengan yang lain saling berkaitan sebagai satu kesatuan sistem. Tetapi untuk keperluan penelitian ini, selanjutnya kita hanya akan lebih fokus untuk membahas pendidikan itu hanya dari aspek kurikulumnya saja. Lebih spesifik lagi bagaimana respon dari lembaga atau pengelola pendidikan itu, dalam menyikapi kurikulum kita yang senantiasa berubah-ubah.

Berdasarkan hasil penelusuran peneliti perihal keberadaan kurikulum yang pernah diterapkan di Indonesia, ada sebuah tulisan yang diungah oleh Ilham D. Matalauni pada bulan Desember 2013 yang menyebutkan bahwa ada 10 macam kurikulum yang pernah berlaku di Indonesia, adapun rinciannya sebagai berikut:

1. Kurikulum 1947 
Bentuknya memuat 2 (dua) hal pokok, yaitu: a). Daftar mata pelajaran dan jam pengajarannya. b). Garis-garis besar pengajaran.

2. Kurikulum 1952

Bentuknya memuat 5 (lima) hal pokok berikut: a). Pendidikan pikiran harus dikurangi. b). Isi pelajaran harus dihubungkan dengan kesenian. c). Pendidikan watak. d). Pendidikan jasmani. Dan e). Kewarganegaraan Masyarakat.

3. Rencana Kurikulum 1964 dan Kurikulum 1964

Bentuknya memuat 5 (lima) hal pokok berikut: a). Manusia Indonesia berjiwa Pancasila. b). Man Power. c). Kepribadian Kebudayaan Nasional yang luhur. d). Ilmu dan teknologi yang tinggi. Dan e). Pergerakan rakyat dan revolusi.

Rencana Pendidikan 1964 melahirkan Kurikulum 1964 yang menitik beratkan pada pengembangan daya cipta, rasa, karsa, karya, dan moral, yang kemudian dikenal dengan istilah Pancawardhana.

\section{Kurikulum 1968}

Dari segi tujuan pendidikan, Kurikulum 1968 bertujuan bahwa pendidikan ditekankan pada upaya untuk membentuk manusia Pancasila sejati, kuat, dan sehat jasmani, mempertinggi kecerdasan dan keterampilan jasmani, moral, budi pekerti, dan keyakinan beragama.

\section{Kurikulum 1975}

Adapun ciri-ciri lebih lengkap kurikulum ini adalah sebagai berikut: a). Berorientasi pada tujuan; menganut pendekatan integratif dalam arti bahwa setiap pelajaran memiliki arti dan peranan yang menunjang kepada tercapainya tujuantujuan yang lebih integratif. b). Menekankan kepada efisiensi dan efektivitas dalam hal daya dan waktu. c). Menganut pendekatan sistem instruksional yang dikenal dengan Prosedur Pengembangan Sistem Instruksional (PPSI). Sistem yang senantiasa mengarah kepada tercapainya tujuan yang spesifik, dapat diukur dan dirumuskan dalam bentuk tingkah laku siswa. Dan d). Dipengaruhi psikologi tingkah laku dengan menekankan kepada stimulus respon (rangsang-jawab) dan latihan (drill).

6. Kurikulum 1984 
Adapun ciri umum kurikulum ini adalah sebagai berikut: a). Berorientasi kepada tujuan instruksional. b). Pendekatan pengajarannya berpusat pada anak didik melalui cara belajar siswa aktif (CBSA). c). Materi pelajaran dikemas dengan nenggunakan pendekatan spiral. d). Menanamkan pengertian terlebih dahulu sebelum diberikan latihan. Dan e). Menggunakan pendekatan keterampilan proses.

\section{Kurikulum 1994}

Adapun ciri umum dari kurikulum ini adalah sebagai berikut: a). Sifat kurikulum objective based curriculum. b). Pembagian tahapan pelajaran di sekolah dengan sistem caturwulan. c). Pembelajaran di sekolah lebih menekankan materi pelajaran yang cukup padat (berorientasi kepada materi pelajaran/isi). d). Kurikulum 1994 bersifat populis, yaitu yang memberlakukan satu sistem kurikulum untuk semua siswa di seluruh Indonesia. Dan e). Dalam pelaksanaan kegiatan, guru menggunakan strategi yang melibatkan siswa aktif dalam belajar, baik secara mental, fisik, dan sosial.

8. Kurikulum Berbasis Kompetensi (KBK) 2004

Depdiknas mengemukakan karakteristik KBK ialah sebagai berikut: a). Menekankan pada ketercapaian kompetensi siswa baik secara individual maupun klasikal. b). Berorientasi pada hasil belajar dan keberagaman. c). Penyampaian dalam pembelajaran menggunakan pendekatan dan metode bervariasi. d). Sumber belajar bukan hanya guru tetapi juga sumber belajar lainnya yang memenuhi unsur edukatif. e). Penilaian menekankan pada proses dan hasil belajar dalam upaya poenguasaan atau pencapaian suatu kompetensi.

9. Kurikulum Tingkat Satuan Pendidikan (KTSP) 2006

Guru memiliki otoritas dalam mengembangkan kurikulum secara bebas dengan memperhatikan karakteristik siswa dan lingkungan di sekolahnya.

10. Kurikulum 2013

Ada empat aspek yang harus diberi perhatian khusus dalam rencana implementasi dan keterlaksanaan kurikulum 2013, yaitu: a). Kompetensi guru dalam pemahaman substansi bahan ajar, yang menyangkut metodologi pembelajaran, yang nilainya pada pelaksanaan uji kompetensi guru (UKG) baru 
mencapai rata-rata 44,46. b). Kompetensi akademik di mana guru harus menguasai metode penyampaian ilmu pengetahuan kepada siswa. c). Kompetensi sosial yang harus dimiliki guru agar tidak bertindak asosial kepada siswa dan teman sejawat lainnya. Dan d). Kompetensi manajerial atau kepemimpinan karena guru sebagai seorang yang akan digugu dan ditiru siswa.

Kesiapan guru sangat urgen dalam pelaksanaan kurikulum ini. Kesiapan guru ini akan berdampak pada kegiatan guru dalam mendorong mampu lebih baik dalam melakukan observasi, bertanya, bernalar, dan mengkomunikasikan apa yang telah mereka peroleh setelah menerima materi pembelajaran.

Sejatinya bukan pada perubahan dari satu kurikulum ke kurikulum lain yang menjadi ganjalan bagi peneliti, karena apabila memang dengan satu pertimbangan atau situasi dan kondisi menghendaki harus ada perubahan mengapa tidak dilakukan perubahan. Akan tetapi, seringkali perubahan dari satu kurikulum ke kurikulum yang lain, tidak diawali dengan evaluasi terhadap kurikulum sebelumnya. Bila dilakukan dengan prosedur yang seharusnya, tentu akan diketahui kelemahan-kelemahan apa saja yang terdapat dalam kurikulum itu, sehingga mengharuskan adanya perubahan. Dan satu hal yang lebih utama, untuk menghindari terjadinya celah-celah kelemahan pada kurikulum yang akan datang. Jangan sampai ada muncul prasangka, kalau perubahan kurikulum yang terjadi selama ini, hanya cenderung mengikuti "selera" pihak-pihak pemangku kebijakan semata.

Lebih lanjut yang harus disadari bersama, bahwa terjadinya perubahan pada kurikulum, bukan semata-mata perubahan dalam hal nama (nomenklatur) semata. Akan tetapi akan diikuti oleh serangkaian perubahan lainnya, seperti perubahan dalam hal metode mengajar, media yang digunakan, pola interaksi di dalam kelas, buku ajar dan lain-lain.

Pihak pertama atau yang sangat merasakan dampak dari adanya perubahan ini adalah lembaga pendidikan atau lebih tepatnya para guru. Pertanyaannya mengapa demikian, karena para gurulah sebagai garda terdepan yang akan mengaplikasikan kurikulum itu dalam proses pembelajarannya. Oleh karenanya, bagus atau jeleknya sebuah kurikulum, bisa dilaksanakan dengan baik atau tidak 
sesungguhnya terpulang kepada para guru di lapangan atau dalam aktifitas pembelajaran di dalam kelas.

Berdasarkan uraian di atas, karena demikian dominannya peranan lembaga pendidikan (khususnya para guru) dalam aplikasi sebuah kurikulum, penelitian ini mempunyai arti penting untuk mengetahui bagaimana respon yang muncul di tingkat akar rumput (grassroots), sebagai bahan pertimbangan bagi para pengambil kebijakan di tingkat pusat. Lebih spesifik penelitian akan menjawab dua permasalahan pokok yaitu: pertama, tingkat pemahaman para guru terhadap kurikulum, dan kedua, respon para guru menyikapi adanya perubahan terhadap kurikulum.

\section{Kajan Pustaka}

Menurut Bobbit yang dikutip oleh Nur Ahid (2006), inti teori kurikulum itu sederhana, yaitu kehidupan manusia. Kehidupan manusia meskipun berbeda-beda pada dasarnya sama, terbentuk oleh sejumah kecakapan pekerjaan. Pendidikan berupaya mempersiapkan kecakapankecakapan tersebut dengan teliti dan sempurna. Kecakapan-kecakapan yang harus dikuasai untuk dapat terjun dalam kehidupan sangat bermacam-macam, bergantung pada tingkatannya maupun jenis lingkungan. Setiap tingkatan dan lingkungan kehidupan menuntut penguasaan pengetahuan, keterampilan, sikap, kebiasaan, apresiasi tertentu. Hal-hal itu merupakan tujuan kurikulum. Untuk mencapai hal-hal itu ada serentetan pengalaman yang harus dikuasai anak. Seluruh tujuan beserta pengalaman-pengalaman tersebut itulah yang menjadi bahan kajian teori kurikulum.

Terkait dengan penelitian ini tentang adanya perubahan yang terjadi dalam kurikulum pendidikan di Indonesia, bisa dimaknai sebagai upaya pengembangan atau penyempurnaan dari kurikulum-kurikulum yang sudah ada. Argumentasinya adalah karena pada kurikulum yang baru, tidak sepenuhnya berbeda dengan kurikulum yang sudah diterapkan sebelumnya.

Kata pengembangan mempunyai banyak arti, pengembangan bisa diartikan sebagai perubahan, pembaharuan, perluasan dan sebagainya. Dalam pengertian yang lazim, pengembangan berarti menunjuk pada suatu kegiatan 
yang menghasilkan cara baru setelah diadakan penilaian serta penyempurnaanpenyempurnaan seperlunya. Sementara itu menurut Surakhmad (1977) pengembangan adalah penyusunan, pelaksanaan, penilaian dan penyempurnaan.

Istilah pengembangan kurikulum mempunyai implikasi bahwa kurikulum senantiasa mengalami perubahan dan perbaikan dengan tetap mengacu pada apa yang sudah ada dan memperhatikan ke depan, sehingga keberadaannya cukup dinamis.

Sedangkan menurut Muhaimin (2005) pengembangan kurikulum dapat diartikan sebagai: (1) kegiatan menghasilkan kurikulum, (2) proses yang mengaitkan satu komponen dengan yang lainnya untuk menghasilkan kurikulum yang lebih baik, dan (3) kegiatan penyusunan (desain), pelaksanaan, penilaian dan penyempurnaan kurikulum.

Nasution (1980) berpendapat bahwa komponen kurikulum yang lazim dan selalu dipertimbangkan dalam pengembangan tiap-tiap kurikulum meliputi: (1) tujuan, (2) bahan pelajaran, (3) proses belajar mengajar dan (4) penilaian.

Selanjutnya John F. Kerr yang dikutip oleh Soetopo dan Soemanto (1993) menyebutkan bahwa pengembangan kurikulum harus memenuhi beberapa kriteria sebagai berikut:

a. Objektif, yakni tujuan yang bersumber dari murid, masyarakat dan ilmu pengetahuan yang meliputi kemampuan kognitif, afektif dan psikomotor.

b. Knowledges, yakni sejumlah pengetahuan yang diintegrasikan dalam pembelajaran.

c. Schoollearning esperiences, yakni sejumlah pengalaman belajar di sekolah yang meliputi isi pelajaran, metode, kesiapan, perbedaan individu, hubungan antara guru dan murid serta hubungan antara masyarakat dan sekolah. 
d. Evaluation, yakni penilaian berdasarkan sejumlah informasi yang dapat dipergunakan untuk mengambil keputusan mengenai perubahan, pengembangan dan penyempurnaan kurikulum.

Berdasarkan uraian di atas, maka pengembangan kurikulum dapat berupa perluasan, penyempurnaan, penambahan dan pengurangan baik sebagian atau perubahan total terhadap komponen kurikulum yang sudah ada berdasarkan hasil penilaian terhadap kurikulum secara terus menerus. Pengembangan kurikulum (curriculum development) menunjuk pada suatu kegiatan yang menghasilkan konsep kurikulum baru yang lebih baik. Dalam hal ini kegiatan pengembangan kurikulum mencakup penyusunan kurikulum itu sendiri, pelaksanaan di sekolah-sekolah yang disertai dengan penilaian secara terus menerus dan melakukan penyempurnaan terhadap komponen-komponen tertentu dari kurikulum yang sudah ada. Selain itu, pengembangan kurikulum mempunyai titik persamaan dan perbedaan. Persamaannya terletak pada tujuan, yaitu pengembangan kurikulum bertujuan untuk meningkatkan kualitas pendidikan. Sedangkan perbedaannya terletak pada proses. Proses pengembangan kurikulum adalah proses mengaitkan komponen yang satu dengan yang lainnya.

Selanjutnya, pengembangan kurikulum sebaiknya dilakukan berdasarkan teori yang telah dikonseptualisasikan secara teliti dan hatihati, dengan demikian berbagai pengaruh yang tidak sesuai dengan pembaharuan maupun ketidakseimbangan kurikulum dapat dihilangkan.

Pengembangan kurikulum adalah istilah yang komprehensif, didalamnya mencakup: perencanaan, penerapan dan evaluasi. Perencanaan kurikulum adalah langkah awal membangun kurikulum ketika pekerja kurikulum membuat keputusan dan mengambil tindakan untuk menghasilkan perencanaan yang akan digunakan oleh guru dan peserta didik. Penerapan Kurikulum atau biasa disebut juga implementasi kurikulum berusaha mentransfer perencanaan kurikulum ke dalam tindakan operasional. Evaluasi kurikulum merupakan tahap akhir dari pengembangan kurikulum untuk menentukan seberapa besar hasil-hasil 
pembelajaran, tingkat ketercapaian program-program yang telah direncanakan, dan hasil-hasil kurikulum itu sendiri. Dalam pengembangan kurikulum, tidak hanya melibatkan orang yang terkait langsung dengan dunia pendidikan saja, namun di dalamnya melibatkan banyak orang, seperti: politikus, pengusaha, orang tua peserta didik, serta unsur-unsur masyarakat lainnya yang merasa berkepentingan dengan pendidikan.

Prinsip-prinsip yang akan digunakan dalam kegiatan pengembangan kurikulum pada dasarnya merupakan kaidah-kaidah atau hukum yang akan menjiwai suatu kurikulum. Dalam pengembangan kurikulum, dapat menggunakan prinsip-prinsip yang telah berkembang dalam kehidupan sehari-hari atau justru menciptakan sendiri prinsipprinsip baru. Oleh karena itu, dalam implementasi kurikulum di suatu lembaga pendidikan sangat mungkin terjadi penggunaan prinsip-prinsip yang berbeda dengan kurikulum yang digunakan di lembaga pendidikan lainnya, sehingga akan ditemukan banyak sekali prinsip-prinsip yang digunakan dalam suatu pengembangan kurikulum. Dalam hal ini, Sukmadinata (2009) mengetengahkan prinsip-prinsip pengembangan kurikulum yang dibagi dalam dua kelompok: (1) prinsip - prinsip umum : relevansi, fleksibilitas, kontinuitas, praktis, dan efektivitas; (2) prinsipprinsip khusus : prinsip berkenaan dengan tujuan pendidikan, prinsip berkenaan dengan pemilihan isi pendidikan, prinsip berkenaan dengan pemilihan proses belajar mengajar, prinsip berkenaan dengan pemilihan media dan alat pelajaran, dan prinsip berkenaan dengan pemilihan kegiatan penilaian.

Sedangkan Asep Herry Hernawan dkk (2002) mengemukakan lima prinsip dalam pengembangan kurikulum, yaitu: prinsip relevansi; secara internal bahwa kurikulum memiliki relevansi di antara komponenkomponen kurikulum (tujuan, bahan, strategi, organisasi dan evaluasi). Sedangkan secara eksternal bahwa komponen-komponen tersebut memiliki relevansi dengan tuntutan ilmu pengetahuan dan teknologi (relevansi epistomologis), tuntutan dan potensi peserta didik (relevansi 
psikologis) serta tuntutan dan kebutuhan perkembangan masyarakat (relevansi sosilogis).

Prinsip fleksibilitas; dalam pengembangan kurikulum mengusahakan agar yang dihasilkan memiliki sifat luwes, lentur dan fleksibel dalam pelaksanaannya, memungkinkan terjadinya penyesuaianpenyesuaian berdasarkan situasi dan kondisi tempat dan waktu yang selalu berkembang, serta kemampuan dan latar bekang peserta didik. Prinsip kontinuitas; yakni adanya kesinambungan dalam kurikulum, baik secara vertikal, maupun secara horizontal. Pengalaman-pengalaman belajar yang disediakan kurikulum harus memperhatikan kesinambungan, baik yang di dalam tingkat kelas, antar jenjang pendidikan, maupun antara jenjang pendidikan dengan jenis pekerjaan. Prinsip efisiensi; yakni mengusahakan agar dalam pengembangan kurikulum dapat mendayagunakan waktu, biaya, dan sumber-sumber lain yang ada secara optimal, cermat dan tepat sehingga hasilnya memadai.

Prinsip efektivitas; yakni mengusahakan agar kegiatan pengembangan kurikulum mencapai tujuan tanpa kegiatan yang mubazir, baik secara kualitas maupun kuantitas.Terkait dengan pengembangan Kurikulum Tingkat Satuan Pendidikan, terdapat sejumlah prinsip-prinsip yang harus dipenuhi, yaitu: Berpusat pada potensi, perkembangan, kebutuhan, dan kepentingan peserta didik dan lingkungannya. Kurikulum dikembangkan berdasarkan prinsip bahwa peserta didik memiliki posisi sentral untuk mengembangkan kompetensinya agar menjadi manusia yang beriman dan bertakwa kepada Tuhan Yang Maha Esa, berakhlak mulia, sehat, berilmu, cakap, kreatif, mandiri dan menjadi warga negara yang demokratis serta bertanggung jawab. Untuk mendukung pencapaian tujuan tersebut pengembangan kompetensi peserta didik disesuaikan dengan potensi, perkembangan, kebutuhan, dan kepentingan peserta didik serta tuntutan lingkungan.

Kurikulum dikembangkan dengan memperhatikan keragaman karakteristik peserta didik, kondisi daerah, dan jenjang serta jenis 
pendidikan, tanpa membedakan agama, suku, budaya dan adat istiadat, serta status sosial ekonomi dan gender. Kurikulum meliputi substansi komponen muatan wajib kurikulum, muatan lokal, dan pengembangan diri secara terpadu, serta disusun dalam keterkaitan dan kesinambungan yang bermakna dan tepat antarsubstansi.

Tanggap terhadap perkembangan ilmu pengetahuan, teknologi, dan seni. Kurikulum dikembangkan atas dasar kesadaran bahwa ilmu pengetahuan, teknologi dan seni berkembang secara dinamis, dan oleh karena itu semangat dan isi kurikulum mendorong peserta didik untuk mengikuti dan memanfaatkan secara tepat perkembangan ilmu pengetahuan, teknologi, dan seni. Relevan dengan kebutuhan kehidupan.

Pengembangan kurikulum dilakukan dengan melibatkan pemangku kepentingan (stakeholders) untuk menjamin relevansi pendidikan dengan kebutuhan kehidupan, termasuk di dalamnya kehidupan kemasyarakatan, dunia usaha dan dunia kerja. Oleh karena itu, pengembangan keterampilan pribadi, keterampilan berpikir, keterampilan sosial, keterampilan akademik, dan keterampilan vokasional merupakan keniscayaan. Menyeluruh dan berkesinambungan. Substansi kurikulum mencakup keseluruhan dimensi kompetensi, bidang kajian keilmuan dan mata pelajaran yang direncanakan dan disajikan secara berkesinambungan antarsemua jenjang pendidikan.

Belajar sepanjang hayat. Kurikulum diarahkan kepada proses pengembangan, pembudayaan dan pemberdayaan peserta didik yang berlangsung sepanjang hayat. Kurikulum mencerminkan keterkaitan antara unsur-unsur pendidikan formal, nonformal dan informal, dengan memperhatikan kondisi dan tuntutan lingkungan yang selalu berkembang serta arah pengembangan manusia seutuhnya.

Seimbang antara kepentingan nasional dan kepentingan daerah. Kurikulum dikembangkan dengan memperhatikan kepentingan nasional dan kepentingan daerah untuk membangun kehidupan bermasyarakat, berbangsa dan bernegara. Kepentingan nasional dan kepentingan daerah 
harus saling mengisi dan memberdayakan sejalan dengan motto Bhineka Tunggal Ika dalam kerangka Negara Kesatuan Republik Indonesia.

Pemenuhan prinsip-prinsip di atas itulah yang membedakan antara penerapan satu Kurikulum Tingkat Satuan Pendidikan dengan kurikulum sebelumnya, yang justru tampaknya sering kali terabaikan. Karena prinsipprinsip itu boleh dikatakan sebagai ruh atau jiwanya kurikulum.

Dalam mensikapi suatu perubahan kurikulum, banyak orang lebih terfokus hanya pada pemenuhan struktur kurikulum sebagai jasad dari kurikulum . Padahal jauh lebih penting adalah perubahan kutural (perilaku) guna memenuhi prinsip-prinsip khusus yang terkandung dalam pengembangan kurikulum.

Kurikulum merupakan komponen sistem pendidikan yang paling rentan terhadap perubahan. Paling tidak ada tiga faktor yang membuat kurikulum harus selalu dirubah atau diperbaharui. Pertama, karena adanya perubahan filosofi tentang manusia dan pendidikan, khususnya mengenai hakikat kebutuhan peserta didik terhadap pendidikan/pembelajaran. Kedua, cara karena cepatnya perkembangan ilmu dan teknologi, sehingga subject matter yang harus disampaikan kepada peserta didik pun semakin banyak dan berragam. Ketiga, adanya perubahan masyarakat, baik secara sosial, politik, ekonomi, mau pun daya dukung lingkungan alam, baik pada tingkat lokal maupun global.

Karena adanya faktor-faktor tersebut, maka salah satu kriteria baik buruknya sebuah kurikulum bisa dilihat pada fleksibilitas dan adaptabilitasnya terhadap perubahan. Selain itu juga dilihat dari segi kemampuan mengakomodasikan isu-isu atau muatan lokal dan isu-isu global. Hal ini diddasarkan pada kenyataan bahwa pendidikan harus mampu mengantarkan peserta didik untuk hidup pada zaman mereka, serta memiliki wawasan global dan mampu berbuat sesuai dengan kebutuhan lokal.

Untuk dapat menuju pada karakteristik kurikulum ideal tersebut maka proses penyusunan kurikulum tidak lagi selayaknya dilakukan oleh 
Negara dan diberlakukan bagi seluruh satuan pendidikan tanpa melihat kondisi internal dan lingkungannya. Kurikulum henaknya disusun dari bawah (bottom up) oleh setiap satuan pendidikan bersama dengan stakeholder masing-masing.

\section{Metode Penelitian}

Jenis penelitian ini adalah penelitian lapangan (field research), dengan pendekatan yang peneliti gunakan adalah kualitatif perspektif naturalistik (naturalistic inquiry), yaitu prosedur penelitian yang menghasilkan data deskriptif berupa kata-kata tertulis atau lisan dari orang-orang dan prilaku yang dapat diamati.

Dalam penelitian ini peneliti hadir langsung di lapangan, karena peneliti merupakan instrumen utama penelitian, yang memang harus hadir sendiri secara langsung di lapangan untuk mengumpulkan data. Langkah ini sejalan dengan pendapat Bogdan dan Biklen (1982), pengumpulan data dalam penelitian kualitatif hendaknya dilakukan sendiri oleh peneliti dan mendatangi sumber datanya secara langsung.

Jenis data dalam penelitian ini, dibedakan menjadi dua yaitu data primer dan data sekunder. Data primer peneliti peroleh dalam bentuk verbal atau kata-kata, ucapan lisan dan perilaku dari subjek (informan) yang berkaitan dengan respon terhadap perubahan kurikulum. Sedangkan data skunder bersumber dari dokumen-dokumen, foto-foto dan benda-benda yang dapat digunakan sebagai pelengkap data primer.

Sumber data dalam penelitian ini dapat dibedakan menjadi dua yaitu: manusia/orang dan bukan manusia. Sumber data manusia berfungsi sebagai subjek atau informan kunci (key informan). Sedangkan sumber data bukan manusia berupa dokumen yang relevan dengan fokus penelitian, seperti gambar, foto, catatan tentang rapat, tulisan-tulisan yang ada kaitannya dengan fokus penelitian.

Penentuan informan dalam penelitian ini dilakukan secara purposif. Teknik purposive sampling digunakan untuk mengarahkan pengumpulan data sesuai dengan kebutuhan-kebutuhan melalui penseleksian dan pemilihan 
informan yang benar-benar menguasai informasi dan permasalahan secara mendalam serta dapat dipercaya untuk menjadi sumber data yang mantap.

Untuk memperoleh data secara holistik dan integratif, serta memperhatikan relevansi data dengan fokus dan tujuan, dalam pengumpulan data peneliti menggunakan tiga teknik, yaitu: (1) wawancara mendalam (indepth inteview); (2) observasi partisipan (participant observation); dan (3) studi dokumentasi (study of documentation). Tiga teknik tersebut merupakan tiga teknik dasar dalam penelitian kualitatif yang disepakati oleh sebagian besar penulis (Bogdan\&Biklen, 1982: Nasution, 1988, Sonhadji dalam Arifin, 1994).

Dalam menetapkan keabsahan data peneliti menggunakan empat kriteria yaitu derajat kepercayaan (credebility), keteralihan (transferability), kebergantungan (dependability), dan kepastian (confirmability).

Langkah terakhir adalah analisis data, yang merupakan proses mencari dan mengatur secara sistematis transkrip wawancara, catatan lapangan, dan bahan-bahan lain yang telah peneliti himpun dari lapangan. Kegiatan analisis dilakukan dengan menelaah data, menata dan membagi menjadi satuan-satuan yang dapat dikelola. Selanjutnya mensistesis, mencari pola, menemukan apa yang bermakana agar dapat dilaporkan secara sistematis.

Kegiatan analisis ini peneliti lakukan secara kontinyu sejak awal data dikumpulkan sampai akhir penelitian. Analisis dan interpretasi ini dilakukan merujuk kepada landasan teoritis yang berhubungan dengan masalah penelitian. Dalam melakukan analisis data, peneliti melakukan analisis model interaktif yang dipelopori oleh Miles dan Huberman (1992) yaitu (1) reduksi data, (2) penyajian data, (3) penarikan kesimpulan dan verifikasi.

\section{B. Pembahasan}

\section{Tingkat Pemahaman Para Guru Terhadap Kurikulum}

Barangkali hampir sama dengan rata-rata guru di sekolah atau madrasah lain, pemahaman para guru di MAN 1 Kudus tentang kurikulum 2013 atau yang biasa disingkat dengan kurtilas, bisa disimpulkan belum sepenuhnya baik. 
Misalnya dalam hal memahami prinsip-prinsip pembelajaran, penilaian dan pembuatan Rencana Program Pengajaran (RPP) yang sesuai dengan semangat kurikulum 2013.

Prinsip-prinsip pembelajaran yang belum dipahami tersebut terutama meliputi: 1) perubahan pendekatan tekstual menuju pendekatan ilmiah, 2) perubahan pembelajaran parsial menuju pembelajaran terpadu, 3) perubahan pembelajaran yang menekankan jawaban tunggal menuju pembelajaran yang membutuhkan jawaban multidimensi, 4) perubahan pembelajaran verbalisme menuju pembelajaran yang aplikatif, dan 5) pembelajaran yang menerapkan prinsip bahwa siapa saja adalah guru, siapa saja adalah siswa, dan dimana saja adalah kelas. Kenyataan tersebut dapat dimaklumi karena selama ini para guru terbiasa menggunakan pembelajaran yang berpusat pada guru (teacher centered) dan guru masih dominan dalam pembelajaran.

Demikian pula dalam hal penilaian yang sesuai dengan Kurikulum 2013, juga dapat diketahui bahwa secara umum para guru belum sepenuhnya memahami kegiatan penilaian. Kegiatan penilaian yang belum dipahami tersebut terutama adalah: 1) bagaimana mengembangkan instrumen penilaian sesuai dengan kaidah, dan 2) bagaimana mengembangkan rubrik penilaian dari instrumen yang dikembangkan tersebut. Hal ini menggambarkan bahwa para guru sebagian besar belum memahami prinsip-prinsip penilaian yang sesuai dengan standar penilaian.

Berdasarkan wawancara yang telah dilakukan, selama ini para guru dalam mengembangkan penilaian masih banyak yang mengadopsi penilaian yang terdapat pada buku-buku tanpa berusaha menyesuaikannya dengan karakteristik siswa di sekolah. Seharusnya para guru dapat mengembangkan instrumen penilaian dan rubriknya sesuai dengan karakteristik dari siswa dan karakteristik sekolah.

Dalam hal penyusunan Rencana Program Pengajaran (RPP) fenomenanya hampir serupa, dapat diketahui bahwa secara umum para guru belum sepenuhnya memahami penyusunan RPP yang sesuai dengan Kurikulum 2013. Ada beberapa prinsip dasar dalam penyusunan RPP yang belum dipahami diantaranya: 1) sumber belajar dapat dari buku teks pelajaran, internet, lingkungan alam dan 
sosial, 2) media pembelajaran dapat bervariasi (baik secara sederhana maupun yang sudah canggih atau multimedia), 3) media harus sesuai dengan materi pembelajaran dan menggunakan pendekatan pembelajaran saintifik. 4) kegiatan pembelajaran mencakup kegiatan-kegiatan pembelajaran, yang sesuai dengan tahapan-tahapan metode saintifik pada inti pembelajaran, 5) kegiatan penutup pembelajaran mencakup kegiatan pengayaan dan/atau remidi, 6) penilaian harus sesuai dengan teknik dan bentuk penilaian autentik, 7) penilaian harus sesuai dengan indikator pencapaian kompetensi, 8) penilaian harus dilengkapi dengan pedoman penskoran.

Menurut analisa peneliti, kenyataan tersebut di atas barangkali dapat dimaklumi, karena para guru sebagian besar belum memahami prinsip-prinsip pembelajaran dan penilaian yang sesuai dengan pedoman yang ada pada Kurikulum 2013. Pemikiran peneliti ini, diperkuat dengan data hasil wawancara bahwa selama ini para guru dalam menyusun RPP, lebih sering mengcopy saja contoh-contoh RPP yang ada, dan kurang berusaha menyesuaikannya dengan situasi dan kondisi sekolah. Pada saat ada tuntutan harus menyusun RPP sesuai dengan prinsip-prinsip pembelajaran dan prinsip-prinsip penilain Kurikulum 2013, mereka semua menjadi kesulitan dan cenderung tidak bisa berbuat apa-apa.

Fakta ini tentunya cukup memprihatinkan, karena sebagian besar mereka adalah para pendidik dengan status sebagai tenaga profesional (telah menerima tunjangan profesi atau sertifikasi). Sebagai pendidik profesional, seyogianya seorang guru tidak hanya dituntut dapat melaksanakan tugasnya secara profesional, melainkan juga harus memiliki pengetahuan dan kemampuan profesional.

Berdasarkan hasil diskusi pengembangan model pendidikan profesional tenaga kependidikan, yang diselenggarakan oleh Program Pascasarjana (PPS) IKIP Bandung tahun 1990, telah dirurumuskan bahwa ciri-ciri suatu profesi yaitu: (1) memiliki fungsi dam signifikansi sosial; (2) memiliki keahlian/keterampilan tertentu; (3) keahlian/keterampilan diperoleh dengan menggunakan teori dan metode ilmiah; (4) didasarkan atas disiplin ilmu yang jelas; (5) diperoleh dengan pendidikan dalam masa tertentu yang cukup lama; (6) aplikasi dan sosialisasi 
nilai-nilai profesional; (7) memiliki kode etik; (8) kebebasan untuk memberikan penilaian (judment) dalam memecahkan masalah dalam lingkup kerjanya; (9) memiliki tanggung jawab profesional; dan (10) adanya pengakuan dari masyrakat dan imbalan atas layanan profesinya.

Selanjutnya, Departemen Pendidikan dan Kebudayaan yang dikutip oleh Sukmadinata (2011) telah merumuskan kemampuan-kemampuan yang harus dimiliki guru, dan mengelompokkannya atas tiga dimensi umum kemampuan, yaitu:

a. Kemampuan profesional, yang mencakup beberapa penguasaan diantaranya: (a) penguasaan materi pelajaran, seperti penguasaan bahan yang akan diajarkan dan dasar keilmuan dari bahan tersebut; (b) penguasaan landasan dan wawasan kependidikan serta keguruan; dan (c) penguasaan proses kependidikan, keguruan dan pembelajaran siswa.

b. Kemampuan sosial, yaitu kemampuan menyesuaikan diri dengan tuntutan kerja dan lingkungan sekitar.

c. Kemampuan personal, yang mencakup: (a) penampilan sikap yang positif terhadap keseluruhan tugasnya sebagai guru, dan terhadap keseluruhan situasi pendidikan; (b) pemahaman, pengayaan, dan penampilan nilai-nilai yang seyogianya dimiliki guru; dan (c) penampilan upaya untuk menjadikan dirinya sebagai anutan dan teladan bagi para siswanya.

Beberapa kriteria tentang ciri-ciri guru profesional di atas, salah satunya dapat dibuktikan dengan tingkat pemahaman mereka terhadap kurikulum, khususnya kurikulum yang terbaru, yaitu kurikulum 2013. Alasan rasionalnya adalah salah satu dimensi pemenuhan terhadap kemampuan profesional, yaitu guru harus menguasai landasan dan wawasan kependidikan serta keguruan. Disamping itu mereka juga harus menguasai proses kependidikan, keguruan dan pembelajaran siswa sesuai dengan tuntutan kurikulum yang diberlakukan.

\section{Respon Guru Dalam Menyikapi Perubahan Kurikulum}

Para guru adalah ujung tombak dalam mengimplementasikan kurikulum pada satuan pendidikan. Oleh karena itu apabila terjadi pergantian kurikulum, 
maka gurulah sebagai pihak pertama yang harus paling siap. Karena hakikat kurikulum itu ada pada guru, jika guru tidak bisa mendalami kurikulum yang berlaku, maka tujuan pendidikan yang diinginkan tidak akan tercapai. Sebaik apapun kurikulum tersebut, tidak akan membuahkan hasil jika guru tidak mampu melaksanakannya.

Kesiapan para guru di MAN 1 Kudus sebagai respon terhadap perubahan kurikulum, khususnya dari kurikulum 2006 ke kurikulum 2013 secara umum belum terlalu siap, mereka belum memahami konsep dan esensi dari kurikulum 2013 sehingga dalam mengimplementasikan kurikulum 2013 cenderung bersikap tekstual sesuai buku pegangan yang ada.

Hambatan paling mendasar dan bisa dikatakan juga utama, yang dihadapi guru dalam implementasi kurikulum 2013 adalah luas dan rumitnya teknik penilaian yang disyaratkan dalam kurikulum 2013 serta belum memadainya buku pegangan yang tersedia.

Persoalan lain adalah adanya sedikit gap atau pertentangan, antara pihak madrasah yang mempunyai kebijakan agar Kurikulum 2013 dapat terus diterapkan, dengan melakukan beberapa upaya yang menunjang pengimplementasian kurikulum tersebut, namun disisi lain para guru ternyata masih belum siap dalam melaksanakan Kurikulum 2013 dengan segala aspeknya.

Menurut analisis peneliti, adanya gap antara kebijakan madrasah dengan kesiapan guru dalam merespon perubahan kurikulum yang terjadi, merupakan akibat dari kurang intensifnya komunikasi antara kedua belah pihak. Artinya kebijakan yang diambil oleh pimpinan madrasah, kurang tersosialisasi dengan baik kepada pihak guru sebagai ujung tombak pelaksana, sebaliknya keluhan guru sebagai ujung tombak pelaksana juga kurang terakomodasi oleh pihak pimpinan madrasah sebagai penentu kebijakan.

Adanya gap yang terjadi merupakan sesuatu yang wajar dalam menyikapi suatu perubahahan, kurangnya pemahaman guru di MAN I Kudus dalam mengimplementasikan kurikulum 2013, tidak menjadikan alasan untuk menghentikan implementasi kurikulum 2013 di MAN I Kudus. Dan bagi pihak 
pimpinan madrasah seyogianya terus melakukan perbaikan, terutama dalam meningkatkan pemahaman guru sebagai pelaksana kurikulum.

Lebih lanjut terkait kurangnya pemahaman yang terjadi, disebabkan oleh kuantitas dan optimalisasi pelatihan yang masih kurang, sehingga sebagai solusi atas permasalahan tersebut, menurut hemat peneliti dapat ditempuh melalui pelaksanaan pelatihan implementasi kurikulum 2013, dengan berbagai ragamnya (in-house training, lesson study, peer teaching) sehingga dapat meningkatkan pemahaman para guru dalam mengimplementasikan kurikulum 2013.

Akan tetapi pada prinsipnya para guru dalam menyikapi kurikulum 2013 cenderung satu suara, yaitu agar kurikulum 2013 segera dilaksanakan untuk menggantikan kurikulum sebelumnya, yang memiliki kelemahan dalam mewujudkan karakter dan moral generasi bangsa. Bila dicermati dari konsep rumusan Standar Kompetensi Lulusan dalam Kurikulum 2013, menggambar arah dan atau tujuan yang dapat mewujudkan insan yang paripurna. Untuk lebih jelasnya marilah kita cermati pernyataan Standar Kompetensi Lulusan kurikulum 2013 tingkat SMA/MA untuk masing-masing ranah:

Pada ranah sikap, dinyatakan bahwa "memiliki perilaku yang mencerminkan sikap orang beriman, berakhlak mulia, berilmu, percaya diri, dan bertanggung jawab dalam berinteraksi secara efektif dengan lingkungan sosial dan alam serta dalam menempatkan diri sebagai cerminan bangsa dalam pergaulan dunia". Pada ranah Pengetahuan, "memiliki pengetahuan faktual, konseptual, prosedural, dan metakognitif dalam ilmu pengetahuan, teknologi, seni, dan budaya dengan wawasan kemanusiaan, kebangsaan, kenegaraan, dan peradaban terkait penyebab serta dampak fenomena dan kejadian". Sedangkan pada ranah keterampilan, "Memiliki kemampuan pikir dan tindak yang efektif dan kreatif dalam ranah abstrak dan konkret sebagai pengembangan dari yang dipelajari di sekolah secara mandiri."

Pernyataan rumusan SKL di atas mengindikasikan bahwa implementasi kurikulum 2013 diharapkan dapat mewujudkan insan yang memiliki sikap orang berakhlak mulia, berilmu, berwawasan luas, produktif dan kreatif. Selain itu, secara konseptual kurikulum 2013 memiliki keunggulan, antara lain: (a) 
menggunakan pendekatan yang bersifat alamiah (kontekstual); (b) berbasis karakter dan kompetensi, sehingga penguasaan terhadap ilmu pengetahuan dapat diaplikasikan siswa dalam kehidupan sehari-hari.

Akhirnya perlu dipahami bersama bahwa bahwa substansi kurikulum 2013 adalah program pendidikan yang bertujuan membentuk karakter, bertanggungjawab, pantang menyerah, berjiwa nasionalisme. Dengan demikian penerapan kurikulum 2013 menjadi tantangan sekaligus peluang bagi para guru untuk mewujudkan cita-cita pendidikan sebagaimana yang tertuang dalam Undang-Undang Dasar 1945 dan Undang-Undang Sistem Pendidikan Nasional.

\section{Kesimpulan}

Guru memegang peranan yang cukup penting dalam melaksanakan suatu perubahan kurikulum. Meskipun guru tidak mencetuskan sendiri konsep-konsep kurikulum, tetapi guru penerjemah perubahan suatu kurikulum. Gurulah yang akan menerjemahkan perubahan suatu kurikulum dengan melakukan pembelajaran dan penilaian terhadap hasil didik kurikulum.

Dari penelitian yang telah dilakukan, berkenaan dengan tingkat pemahaman para guru terhadap kurikulum, kiranya masih perlu senantiasa mendapat perhatian yang serius terutama oleh pimpinan madrasah. Hal-hal yang perlu diperhatikan, khususnya menyangkut pemahaman guru terhadap prinsipprinsip pembelajaran, pembuatan RPP dan penilaian yang sesuai dengan Kurikulum 2013.

Mengenai respon para guru menyikapi adanya perubahan terhadap kurikulum, secara umum terbagi dua yaitu ada yang pro (menerima) dan ada juga yang kontra (menolak). Meskipun para guru sesungguhnya sangat menyadari bahwa suatu perubahan atau inovasi mengandung arti adanya perubahan dari suatu keadaan yang lama untuk menjadi lebih baik.

Oleh karena itu, kegiatan-kegiatan yang diharapkan para guru untuk mempersiapkan mereka melaksanakan kurikulum 2013 adalah pembinaan para guru, pelatihan dan seminar, pembekalan lanjutan, pelatihan dan pendampingan 
langsung, melaksanakan sosialisasi secara berkelanjutan serta menyediakan tutor dan fasilitator yang profesional.

\section{Daftar Pustaka}

Bogdan and Biklen. (1982). Qualitative Research For Education, An Introduction to Theory and Methods. Boston: Allyn and Bacon.

Hernawan, Asep Herry., et al. (2002). Pengembangan Model Pembelajaran Berbasis Komputer. Bandung: Jurusan Kurikulum dan Teknologi Pendidikan.

Ilham D. Matalauni at Selasa, Desember 17, 2013, http://musbir.blogspot.com/2013/07/kurikulum-yang-pernah-berlakudi.html

Miles, M. B and Huberman, A. M. (1994). Qualitative Data Analysis. Second Edition, London: Sage.

Muhaimin. (2005). Pengembangan Kurikulum Pendidikan Islam di Sekolah. Madrasah dan Perguruan Tinggi. Jakarta: Rajawali Press.

Nasution, S. (1980). Mengajar Dengan Sukses, Bandung: Jemmars.

Nur Ahid, "Konsep dan Teori Kurikulum dalam Dunia Pendidikan", ISLAMICA, Vol. 1, No. 1, September 2006.

Soetopo, Hendiyat dan Wasty Soemanto. (1993). Pembinaan dan Pengembangan Kurikulum Sebagai Substansi Problem Administrasi Pendidikan. Jakarta: Bina Aksara.

Sukmadinata, N.S. (2009). Pengembangan Kurikulum Teori dan Praktek, Bandung: PT Remaja Rosdakarya.

Surakhmad, Winarno. (1977). Pembinaan dan Pengembangan Kurikulum, Jakarta: Proyek Pengadaan Buku Sekolah Pendidikan Guru. 